Groundwater Resources Program

\title{
Water-Level Changes and Change in Water in Storage in the High Plains Aquifer, Predevelopment to 2013 and 2011-13
}

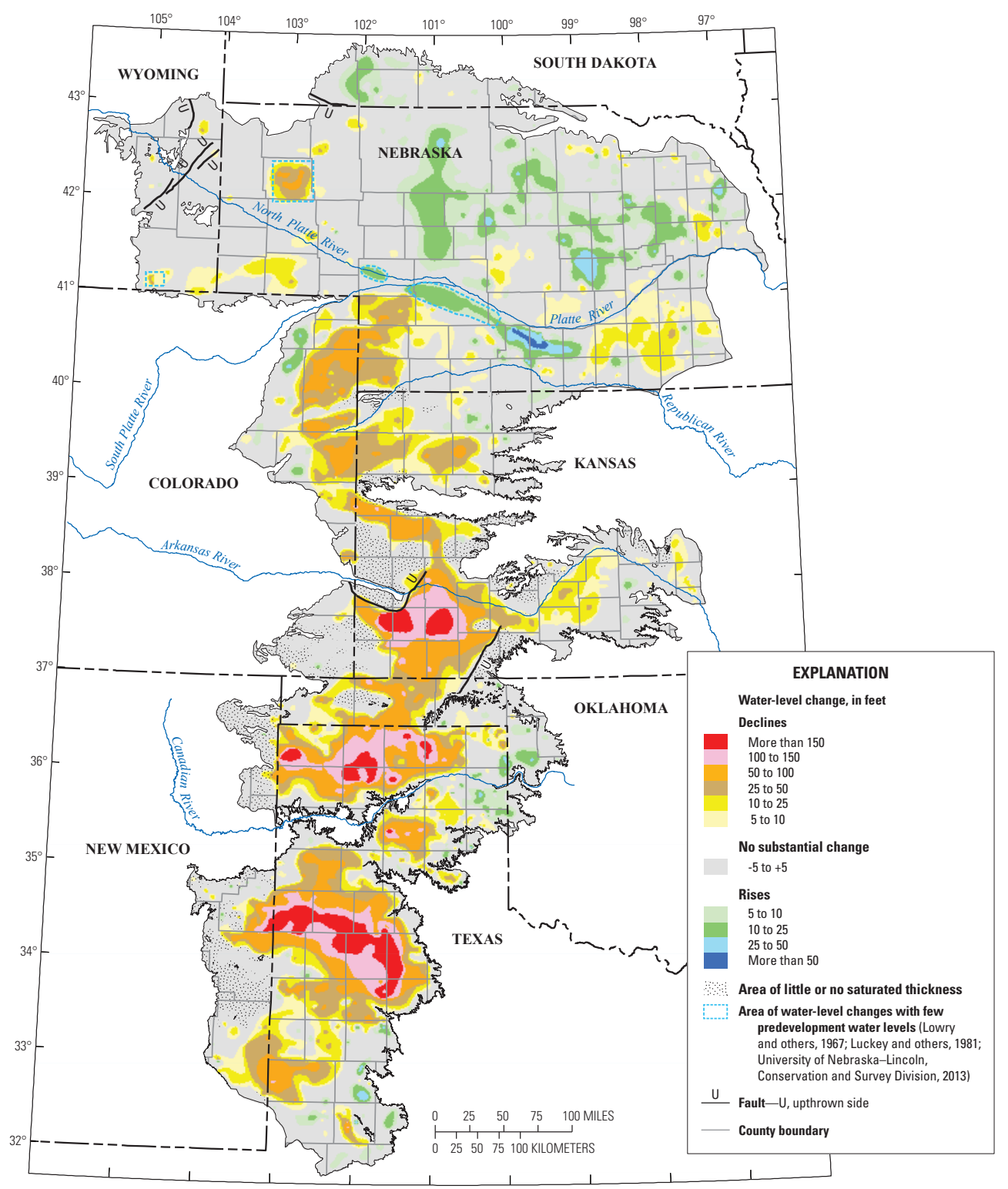

Scientific Investigations Report 2014-5218 
Cover illustration: Modified version of figure 1 from this report. 


\section{Water-Level Changes and Change in Water in Storage in the High Plains Aquifer, Predevelopment to 2013 and 2011-13}

By Virginia L. McGuire

Groundwater Resources Program

Scientific Investigations Report 2014-5218 


\title{
U.S. Department of the Interior SALLY JEWELL, Secretary
}

\section{U.S. Geological Survey Suzette M. Kimball, Acting Director}

\author{
U.S. Geological Survey, Reston, Virginia: 2014
}

For more information on the USGS - the Federal source for science about the Earth, its natural and living resources, natural hazards, and the environment, visit http://www.usgs.gov or call 1-888-ASK-USGS.

For an overview of USGS information products, including maps, imagery, and publications, visit http://www.usgs.gov/pubprod

To order this and other USGS information products, visit http://store.usgs.gov

Any use of trade, firm, or product names is for descriptive purposes only and does not imply endorsement by the U.S. Government.

Although this information product, for the most part, is in the public domain, it also may contain copyrighted materials as noted in the text. Permission to reproduce copyrighted items must be secured from the copyright owner.

Suggested citation:

McGuire, V.L., 2014, Water-level changes and change in water in storage in the High Plains aquifer, predevelopment to 2013 and 2011-13: U.S. Geological Survey Scientific Investigations Report 2014-5218, 14 p., http://dx.doi. org/10.3133/sir20145218.

ISSN: 2328-0328 (online) 


\section{Contents}

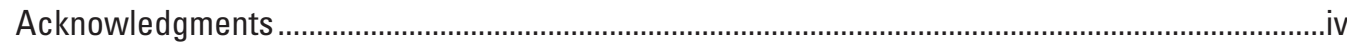

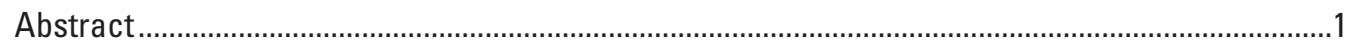

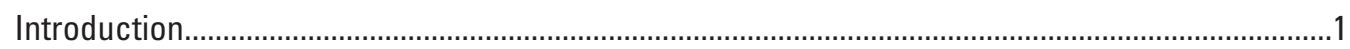

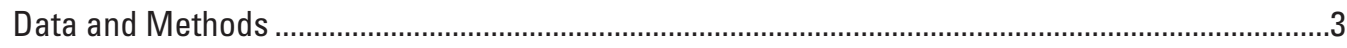

Characteristics of Raster Datasets ......................................................................................

Characteristics of Water-Level Data .................................................................................

Characterizing Water-Level Changes, Predevelopment to 2013 ................................................5

Characterizing Water-Level Changes, 2011-13 …………………………………..............

Characterizing Specific Yield .............................................................................................

Calculation of Area-Weighted, Average Water-Level Changes, Predevelopment to

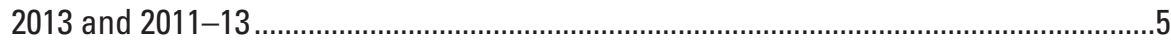

Calculation of Total Water in Storage and Change in Water in Storage .................................5

Characterizing Percentage Change in Saturated Thickness, Predevelopment to 2013 ...........6

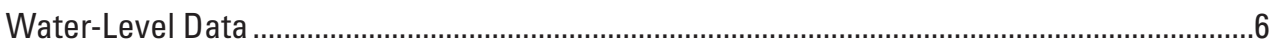

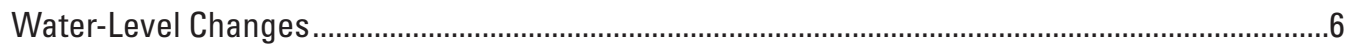

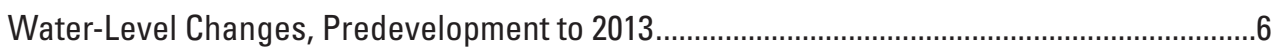

Water-Level Changes, 2011-13..................................................................................................

Percentage Change in Saturated Thickness, Predevelopment to 2013 ...................................7

Change in Water in Storage, Predevelopment to 2013 and 2011-13................................................7

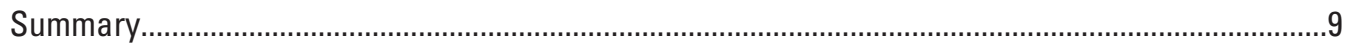

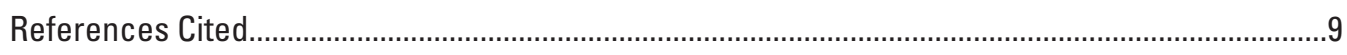

Appendix. Raster Datasets.....................................................................................................

\section{Figures}

1. Map showing water-level changes in the High Plains aquifer, predevelopment (about 1950) to 2013 ......................................................................................................

2. Map showing change in saturated thickness of the High Plains aquifer, predevelop-

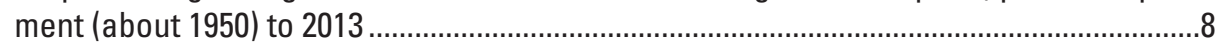

\section{Tables}

1. Number of wells used in this report for 2011, 2012, and 2013 water levels, and for the water-level comparison periods, predevelopment to 2013 and 2011-13, by State and in total for the High Plains aquifer.

2. Area-weighted, average water-level changes in the High Plains aquifer, not including areas of little or no saturated thickness, predevelopment to 2013 and 2011-13, by State and as an overall total.

3. Change in water in storage in the High Plains aquifer, predevelopment to 2013 and 2011-13, by State and as an overall total.. 


\section{Conversion Factors}

\begin{tabular}{|c|c|c|}
\hline Multiply & By & To obtain \\
\hline \multicolumn{3}{|c|}{ Length } \\
\hline foot $(\mathrm{ft})$ & 0.3048 & meter $(\mathrm{m})$ \\
\hline \multicolumn{3}{|c|}{ Area } \\
\hline acre & 4,047 & square meter $\left(\mathrm{m}^{2}\right)$ \\
\hline square foot $\left(\mathrm{ft}^{2}\right)$ & 0.09290 & square meter $\left(\mathrm{m}^{2}\right)$ \\
\hline square mile $\left(\mathrm{mi}^{2}\right)^{*}$ & 2.590 & square kilometer $\left(\mathrm{km}^{2}\right)$ \\
\hline \multicolumn{3}{|c|}{ Volume } \\
\hline gallon (gal) & 3.785 & liter $(\mathrm{L})$ \\
\hline gallon (gal) & 0.003785 & cubic meter $\left(\mathrm{m}^{3}\right)$ \\
\hline cubic foot $\left(\mathrm{ft}^{3}\right)$ & 0.02832 & cubic meter $\left(\mathrm{m}^{3}\right)$ \\
\hline acre-foot (acre-ft)** & 1,233 & cubic meter $\left(\mathrm{m}^{3}\right)$ \\
\hline million acre-foot (Macre-ft) & $4,047,000,000$ & square meter-foot $\left(\mathrm{m}^{2}-\mathrm{ft}\right)$ \\
\hline million acre-foot (Macre-ft) & 1.233 & cubic kilometer $\left(\mathrm{m}^{3}\right)$ \\
\hline
\end{tabular}

*There are 640 acres in a square mile $\left(\mathrm{mi}^{2}\right)$.

** One acre-foot of water is equivalent to the volume of water that would cover 1 acre $\left(43,560 \mathrm{ft}^{2}\right)$ to a depth of 1 foot $\left(325,851\right.$ gallons or $\left.43,560 \mathrm{ft}^{3}\right)$.

Horizontal coordinate information is referenced to the North American Datum of 1983 (NAD 83).

Water year is the 12-month period, 0 ctober 1 through September 30 , and is designated by the calendar year in which it ends.

\section{Acknowledgments}

Most of the water-level data used in this report were provided by the following State, local, and Federal entities: Colorado-Division of Water Resources (also known as the Office of the State Engineer); Kansas-Department of Agriculture, Division of Water Resources and the Kansas Geological Survey; Nebraska-Central Nebraska Public Power and Irrigation District, Natural Resources Districts, and University of Nebraska-Lincoln, Conservation and Survey Division; New Mexico-Office of the State Engineer; Oklahoma-Water Resources Board; South Dakota-Department of Environment and Natural Resources; Texas-Groundwater Conservation Districts and the Water Development Board; Wyoming-State Engineer's Office; and Federal-Bureau of Reclamation and U.S. Fish and Wildlife Service. The author thanks the above entities for providing the water-level data and for their responsiveness regarding questions about the data. 


\title{
Water-Level Changes and Change in Water in Storage in the High Plains Aquifer, Predevelopment to 2013 and 2011-13
}

\author{
By Virginia L. McGuire
}

\section{Abstract}

The High Plains aquifer underlies 111.8 million acres (about 175,000 square miles) in parts of eight States-Colorado, Kansas, Nebraska, New Mexico, Oklahoma, South Dakota, Texas, and Wyoming. Water-level declines began in parts of the High Plains aquifer soon after the beginning of substantial irrigation with groundwater in the aquifer area (about 1950). This report presents water-level changes in the High Plains aquifer from predevelopment (generally before 1950) to 2013 and from 2011 to 2013 . The report also presents change in water in storage in the High Plains aquifer from predevelopment to 2013 and from 2011 to 2013.

The methods to calculate area-weighted, average waterlevel changes; change in water in storage; and total water in storage for this report used geospatial data layers organized as rasters with a cell size of 500 meters by 500 meters, which is an area of about 62 acres. These methods were used to provide a raster dataset of water-level changes for other uses.

Water-level changes from predevelopment to 2013, by well, ranged from a rise of 85 feet to a decline of 256 feet. Water-level changes from 2011 to 2013, by well, ranged from a rise of 19 feet to a decline of 44 feet. The area-weighted, average water-level changes in the aquifer were an overall decline of 15.4 feet from predevelopment to 2013, and a decline of 2.1 feet from 2011 to 2013 . Total water in storage in the aquifer in 2013 was about 2.92 billion acre-feet, which was a decline of about 266.7 million acre-feet since predevelopment and a decline of 36.0 million acre-feet from 2011 to 2013.

\section{Introduction}

The High Plains aquifer underlies 111.8 million acres (about 175,000 square miles [mi $\left.{ }^{2}\right]$ ) in parts of eight StatesColorado, Kansas, Nebraska, New Mexico, Oklahoma, South Dakota, Texas, and Wyoming (fig. 1; Qi, 2010). In the High Plains aquifer, groundwater generally is under unconfined conditions, and the water body, from a regional perspective, has a water table at which the water pressure is atmospheric (Weeks and Gutentag, 1981). The saturated thickness of the aquifer, which is the distance from the water table to the base of the aquifer, ranges from less than 50 feet (ft) to about 1,200 ft (McGuire and others, 2012). Gutentag and others (1984) reported that, in a few parts of the aquifer area, the water table is discontinuous; these areas total about 6.0 million acres $\left(10,780 \mathrm{mi}^{2}\right)$ and are labeled in this report's figures as "area of little or no saturated thickness." Wells drilled in areas of little or no saturated thickness (fig. 1) likely will not yield water unless the wells penetrated saturated sediment in buried channels or depressions in the bedrock surface (Gutentag and others, 1984).

The area overlying the High Plains aquifer is one of the primary agricultural regions in the Nation; in parts of the area, farmers and ranchers began extensive use of groundwater for irrigation in the 1930s and 1940s. Estimated irrigated acreage was 2.1 million acres in 1949, 13.7 million acres in 1980, 13.9 million acres in 1997, 12.7 million acres in 2002, and 15.5 million acres in 2005 (Heimes and Luckey, 1982; Thelin and Heimes, 1987; U.S. Department of Agriculture, 1999 and 2004; Kenny and others, 2009). In 2005, about 14 percent of the aquifer area was irrigated, not including the areas with little or no saturated thickness (Kenny and others, 2009).

About every 5 years, groundwater withdrawals for irrigation and other uses are compiled from water-use data and reported by the U.S. Geological Survey (USGS) and State agencies. Groundwater withdrawals from the High Plains aquifer for irrigation increased from 4 to 19 million acre-feet (Macre-ft) from 1949 to 1974; groundwater withdrawals for irrigation in $1980,1985,1990$, and 1995 were 4 to 18 percent less than withdrawals for irrigation in 1974 (Heimes and Luckey, 1982; U.S. Geological Survey, 2008). Groundwater withdrawals from the aquifer for irrigation were 21 Macre-ft in 2000 (Maupin and Barber, 2005) and estimated as 19 Macre-ft in 2005 (U.S. Geological Survey, 2008; Kenny and others, 2009; McGuire, 2009).

Water-level declines began in parts of the High Plains aquifer soon after the onset of substantial irrigation using 


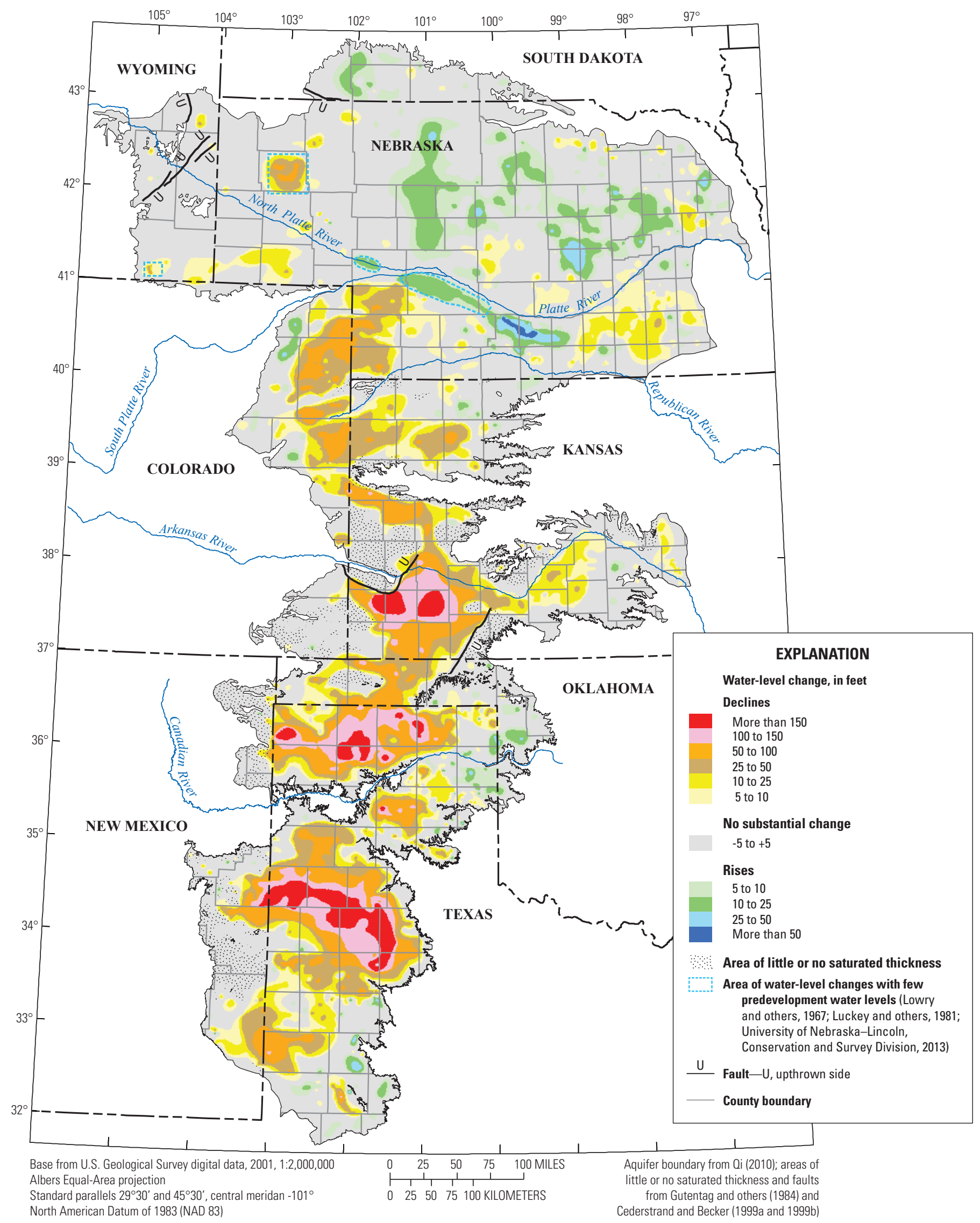

Figure 1. Water-level changes in the High Plains aquifer, predevelopment (about 1950) to 2013. 
groundwater in the area-about 1950 (Gutentag and others, 1984). By 1980, water levels in the High Plains aquifer in parts of Texas, Oklahoma, and southwestern Kansas had declined more than $100 \mathrm{ft}$ (Luckey and others, 1981).

Changes in the static water-level of an aquifer result from an imbalance between discharge and recharge. The static water level in a well is the water level after recovery from pumping in the measured well or in nearby wells. Discharge from the High Plains aquifer primarily consists of groundwater withdrawals for irrigation; but also includes groundwater withdrawals for public water supply and other uses; evapotranspiration where the water table is near land surface; and seepage to streams, springs, and other surfacewater bodies, where the water table intersects the land surface (Maupin and Barber, 2005). Recharge to the aquifer primarily is from precipitation, but other sources of recharge include irrigation return flows and seepage from streams, canals, and reservoirs (Luckey and Becker, 1999). Water-level declines may result in increased costs to pump groundwater because of increased pumping lift and decreased well yields (Taylor and Alley, 2001). Water-level declines also can affect groundwater availability, surface-water flow, and near-stream (riparian) habitat areas (Alley and others, 1999).

In response to water-level declines, Congress, under the authority of Title III to the Water Resources Research Act (U.S. Public Law 98-242, 99-662), directed the USGS to monitor water levels in the High Plains aquifer. Since 1987, the USGS, in collaboration with numerous State, local, and Federal water-resources entities, have compiled water levels from wells completed in the High Plains aquifer. Water levels were measured in 8,332 wells for 2011 and 8,910 wells for 2012; water levels for 2013 were based on measurements from 8,613 wells (table 1 ).

Purposes of this report are (1) to present water-level changes in the High Plains aquifer from the time before substantial development of groundwater for irrigation (referred to hereinafter as "predevelopment") to 2013 and from 2011 to 2013 (referred to hereinafter as 2011-13), (2) to present changes in drainable water in storage, which will hereinafter be referred as "water in storage," in the High Plains aquifer from predevelopment to 2013 and from 2011-13, and (3) to publish the raster dataset depicting water-level changes from predevelopment to 2013. Predevelopment generally is before about 1950, but in some areas (for example, in the north-central part of the Texas Panhandle), predevelopment is the late 1990s, and in other areas (for example, in northcentral Nebraska), currently (2014), groundwater has not been substantially developed for irrigation. Water in storage is the fraction of water in the aquifer that will drain by gravity and can be withdrawn by wells. The remaining water in the aquifer is held to the aquifer material and generally cannot be withdrawn by wells (Meinzer, 1923). Water levels used in this report generally were measured in winter or early spring, when irrigation wells typically were not pumping, and after water levels generally had recovered from pumping during the previous irrigation season.
Table 1. Number of wells used in this report for 2011, 2012, and 2013 water levels, and for the water-level comparison periods, predevelopment to 2013 and 2011-13, by State and in total for the High Plains aquifer.

\begin{tabular}{|c|c|c|c|c|c|}
\hline \multirow{2}{*}{ State } & \multicolumn{3}{|c|}{$\begin{array}{l}\text { Number of wells } \\
\text { measured }\end{array}$} & \multicolumn{2}{|c|}{$\begin{array}{l}\text { Number of wells used in } \\
\text { water-level comparison } \\
\text { for indicated period }\end{array}$} \\
\hline & 2011 & 2012 & 2013 & $\begin{array}{l}\text { Predevelop- } \\
\text { ment to } 2013\end{array}$ & 2011-13 \\
\hline Colorado & 511 & 450 & 445 & 325 & 411 \\
\hline Kansas & 1,419 & 1,645 & 1,579 & 506 & 1,253 \\
\hline Nebraska & 3,306 & 3,673 & 3,514 & 1,508 & 3,099 \\
\hline New Mexico & 115 & 149 & 120 & $100 *$ & 30 \\
\hline Oklahoma & 143 & 154 & 150 & 80 & 133 \\
\hline South Dakota & 105 & 85 & 103 & 68 & 98 \\
\hline Texas & 2,681 & 2,699 & 2,688 & 745 & 2,424 \\
\hline Wyoming & 52 & 55 & 14 & $17 * *$ & 12 \\
\hline $\begin{array}{l}\text { High Plains } \\
\text { aquifer }\end{array}$ & 8,332 & 8,910 & 8,613 & 3,349 & 7,460 \\
\hline
\end{tabular}

*For 67 wells in the predevelopment-to-2013 water-level comparison period, 2009, 2010, 2011, or 2012 water levels were used instead of 2013 water levels because many wells in New Mexico were measured only once every 5 years or because the 2013 water level was not a static water level.

**For 16 wells in the predevelopment-to-2013 water-level comparison period, 2012 water levels were used instead of 2013 water levels because many wells in Wyoming, which were measured in predevelopment, were not measured in 2013.

\section{Data and Methods}

Area-weighted, average water-level changes, predevelopment to 2013 and 2011-13; change in water in storage, predevelopment to 2013 and 2011-13; and total water in storage in 2013 were calculated for this report using geospatial data organized as rasters datasets (hereinafter, "rasters"). The rasters used included saturated thickness as of 2009 (McGuire and others, 2012); change in water in storage, 2009-11 (McGuire, 2013); change in water in storage, 2011-13 (this report); and specific yield (McGuire and others, 2012). The methods used for these calculations are generally the same as methods used in McGuire (2013); these methods provide a final, raster dataset of water-level changes, from predevelopment to 2013, for other uses.

\section{Characteristics of Raster Datasets}

In this report, rasters, presented as maps and summarized with statistics, were generated for water-level changes and percent changes in saturated thickness from predevelopment to 2013. The rasters were generated using Esri ${ }^{\circledR}$ ArcInfo $^{\mathrm{TM}}$ Workstation, version 10.0, a geographic information system (Esri, 1992 and 2010), which will hereinafter be referred as "GIS." The rasters are georeferenced to geographic coordinates on an 
Albers equal-area conic projection using the North American Datum of 1983 (NAD 83). The cell size for all rasters was 500 meters $(\mathrm{m})$ by $500 \mathrm{~m}$ or about 62 acres. Water-levelchange values were stored in units of feet. Changes in water in storage values were stored in units of square meter-feet $\left(\mathrm{m}^{2}-\mathrm{ft}\right)$. Water in storage was summarized in units of Macre-ft. The raster of water-level changes, predevelopment to 2013, is available in two formats at the website listed in the Appendix. An additional raster for water-level changes, 2011-13, was generated and summarized with statistics, but not shown in this report.

The interpolation process used to generate the rasters, which are referred to in this report, results in cell values, for cells collocated with a measured well, that are generally similar to, but commonly not exactly equal to, the corresponding values based on those water-level measurements. The cell values represent the value for an area $500-\mathrm{m}$ by $500-\mathrm{m}$ and the measured values are point values within the area represented by the cell.

\section{Characteristics of Water-Level Data}

Water-level data used in this report generally were from wells measured with an electric or steel tape using methods similar to those described by Cunningham and Schalk (2011). The wells were measured by numerous State, local, and Federal water-resources agencies, and the measurement results were loaded into the USGS National Water Information System (NWIS) (U.S. Geological Survey, 2014).

Most of the wells were measured manually one to two times per water year. The water year starts with October of the previous year and ends with September of the given year. Generally, if a well was measured one time per water year, the well was measured in the winter or early spring; if a well was measured two times per water year, the well was measured in winter or early spring and in the fall. Some wells were measured nearly continuously using instrumentation (data recorders with sensors or floats) installed in the well that recorded the water level periodically (generally every 15 to 60 minutes) (Cunningham and Schalk, 2011). Waterlevel data used to map water-level changes were compiled for the specified water years (U.S. Geological Survey, 2014). Available water-level data for each well were reviewed to select a water level that (1) best represents the static water level for each applicable water year and (2) is consistent with water levels in nearby wells. If a static water level was not available for a given well for the specified water year, the water-level data for that well for the specified water year were not used in this report, except as noted in table 1.

Most of the measured wells supply water for irrigation; water-level precision and accuracy in irrigation wells can be adversely affected by excess oil used to lubricate the well's pump. The thickness of the excess oil and the depth to the oil-water interface can be measured with specialized waterlevel tapes or can be estimated using a method described in Cunningham and Schalk (2011). The specialized tapes often cannot be used in irrigation wells because opening(s) in the well casing for the tape generally are too small for the specialized tape. In this report, it is assumed that, if there is not oil in the well, the precision of the water-level measurements is $0.01 \mathrm{ft}$; if there is oil on the surface of the water, the precision of the water-level measurement likely is greater than $0.01 \mathrm{ft}$. The accuracy of the water-level measurement can be affected by many factors (Cunningham and Schalk, 2011); if there is oil on the surface of the water, the error in the waterlevel measurement could be as much as $5 \mathrm{ft}$, depending on the depth of the oil and whether the methods described in Cunningham and Schalk (2011) are used to correct the waterlevel measurement.

In all eight States underlain by the High Plains aquifer, available water levels for predevelopment and 1980 were compiled by Weeks and Gutentag (1981) and McGuire and others (2003). The predevelopment water level generally was estimated by using the earliest water-level measurement available for more than 20,000 wells. The median measurement year in the predevelopment period was 1957 (McGuire and others, 2003). The 1980 water levels are static water levels generally measured after the irrigation season in 1979 and before the irrigation season in 1980 (that is, in water year 1980), but some were measured 1 or 2 years earlier.

In seven of the eight States that are underlain by the High Plains aquifer-Colorado, Kansas, Nebraska, Oklahoma, South Dakota, Texas, and Wyoming - most water-level data used in this report were from wells measured annually. In areas underlain by the High Plains aquifer in New Mexico, a substantial number of wells are measured only once every 5 or more years.

In Colorado, Kansas, Nebraska, Oklahoma, South Dakota, and Texas, the water levels used to map water-level changes, predevelopment to 2013, were from wells with a static water level for predevelopment and for 2013. In New Mexico and Wyoming, the water levels used to map waterlevel changes, predevelopment to 2013, were from wells with a static water level for predevelopment, and a measured or estimated static water level for 2013.

Water levels for 2013 were estimated for wells in New Mexico using the most recent static water levels from 2009 to 2012 , for wells not measured or without a static water level for 2013. A total of 67 water levels were estimated for 2013 for wells in New Mexico; these estimates used water levels measured in 2009 for 5 wells, in 2010 for 1 well, in 2011 for 23 wells, and in 2012 for 38 wells. Water levels for 2013 were estimated for wells in Wyoming using the most recent static water levels from 2012 for 16 wells not measured or without a static water level for 2013.

In the eight States that are underlain by the High Plains aquifer, the water levels used to map 2011-13 water-level changes were from wells with a measured static water level for 2011 and 2013. Estimated water levels were not used to map 2011-13 water-level changes. 


\section{Characterizing Water-Level Changes, Predevelopment to 2013}

The raster of water-level changes, predevelopment to 2013, was generated using the same methods used in McGuire (2013) for the raster of water-level changes, predevelopment to 2011. The raster was generated using the GIS command "topogrid" with the water-level-change data from wells measured in predevelopment and measured or estimated for 2013 as the primary source data and contours of water-level change, to control the interpolation. The contours of water-level change, which were used to control the interpolation, were generated using primary and supplemental water-level-change data from wells measured in predevelopment and measured or estimated for 2013 and from published water-level change values in areas in Nebraska and Wyoming with sparse primary or supplemental water-level-change data (Lowry and others, 1967; Luckey and others, 1981; University of NebraskaLincoln, Conservation and Survey Division, 2013). The supplemental water-level-change data for the predevelopmentto-2013 period were from the following sources:

1. Wells measured before June 15, 1978, but not during or before the predevelopment period for the area, and in 2013; and

2. Wells measured in 1980 and 2013.

The mapped areas between a decline of less than $5 \mathrm{ft}$ and a rise of less than $5 \mathrm{ft}$ were termed areas of no substantial change and were assigned a value of zero water-level change rather than using the GIS interpolation of water-level change values in these areas. McGuire (2013) discusses the effect of using zero in the areas of no substantial changes instead of the GIS interpolation of water-level change values in these areas.

\section{Characterizing Water-Level Changes, 2011-13}

The raster of water-level changes, 2011-13, was generated using the GIS command "topogrid," which is the same method used in McGuire (2013) for the raster of water-level changes, 2009-11. The mapped areas between a decline of less than $1 \mathrm{ft}$ and a rise of less than $1 \mathrm{ft}$ were termed areas of no substantial change and were assigned a value of zero water-level change rather than using the GIS interpolation of water-level change values in these areas. McGuire (2013) discusses the effect of using zero in the areas of no substantial changes instead of the GIS interpolation of water-level change values in these areas. The area of no substantial change for the 2011-13 time period was defined differently than the range used for the predevelopment to 2013 time period because there were many water-level change values in the 2011-13 time period that are between a decline of less than $1 \mathrm{ft}$ and a rise of less than $1 \mathrm{ft}$.

\section{Characterizing Specific Yield}

Specific yield of the aquifer is needed to calculate water in storage. Specific yield of a rock or soil, with respect to water, is the ratio of the volume of water, which the saturated rock or soil will yield by gravity, to the rock or soil volume (Meinzer, 1923). Specific yield was mapped for the High Plains aquifer from point estimates of area-weighted, average specific yield derived from lithologic logs for selected wells or test holes generally drilled to the base of the aquifer. The areaweighted, average specific yield of the High Plains aquifer ranges from near 0 to 30 percent. The area-weighted, average specific yield, not including the areas of little or no saturated thickness, ranges by State, from 8.1 percent in Wyoming to 18.5 percent in Oklahoma and is 15.1 percent overall for the aquifer (Gutentag and others, 1984; McGuire and others, 2012).

A specific-yield raster was created from a digital map of specific-yield ranges in the High Plains aquifer (Gutentag and others, 1984; Cederstrand and Becker, 1998). The GIS command "polygrid" was used to convert the average of the assigned range for the specific-yield polygons to a raster of the area (McGuire and others, 2012). The specific-yield value of cells in this raster of specific yield is hereafter referred to as the "average-mapped" specific-yield value.

\section{Calculation of Area-Weighted, Average Water- Level Changes, Predevelopment to 2013 and 2011-13}

In this report, area-weighted, average water-level changes, predevelopment to 2013 and 2011-13, were calculated using the same methods used in McGuire (2013) to calculate area-weighted, average water-level changes, predevelopment to 2011 and 2009-11. This method for calculating area-weighted, average water-level changes was used because the final raster can be used to easily calculate statistics for additional subareas of the aquifer.

\section{Calculation of Total Water in Storage and Change in Water in Storage}

Total water in storage for 2013 was calculated, using the respective raster cell values, by summing the rasters of saturated thickness for 2009 (McGuire and others, 2012) and the rasters of water-level changes from 2009-11(McGuire, 2013) and 2011-13, then multiplying the result by the raster of average-mapped specific yield (McGuire and others, 2012) and by a conversion factor to convert units of square meter-feet to million acre-feet. Changes in water in storage in the High Plains aquifer for the predevelopment to 2013 and the 2011-13 time periods were calculated in this report by applying "map algebra" techniques (Tomlin and Berry, 1979) to coregistered rasters sharing a common cell size and 
mesh orientation. The raster cell values of water-level changes for each period were multiplied by the raster cell values of average-mapped specific yield (McGuire and others, 2012) and by a conversion factor to convert units of square meterfeet to million acre-feet. Changes in water in storage from predevelopment to 2013 and 2011-13, by State and as an overall High Plains aquifer total, were calculated using the applicable resultant raster.

\section{Characterizing Percentage Change in Saturated Thickness, Predevelopment to 2013}

The raster of percentage change in saturated thickness, predevelopment to 2013, was generated using the GIS command "topogrid." Inputs to topogrid were percent change in saturated thickness at each well measured in predevelopment and measured or estimated for 2013 and contours of percent change in saturated thickness. Predevelopment saturated thickness was calculated for each well by subtracting the altitude of the base of aquifer from the predevelopment water-level altitude. The contours of percent change in saturated thickness were used to constrain the interpolation in areas of sparse data; the contours of percent change in saturated thickness were generated using the percent change in saturated thickness at each well measured in predevelopment and measured or estimated for 2013 and published areas of water-level level changes in Nebraska and Wyoming with few predevelopment water levels, (Lowry and others, 1967; Luckey and others, 1981; University of Nebraska-Lincoln, Conservation and Survey Division, 2013). The percent change in saturated-thickness contours were reviewed and manually modified using supplemental data to construct the final contours. The supplemental data for changes in saturated thickness, in percent, were from the following sources:

1. Wells measured before June 15,1978 , but not in the predevelopment period for the area, and in the 2013 period; and

2. Wells measured in 1980 and in the 2013 period.

\section{Water-Level Data}

Water-level data used in this report were provided by the following State, local, and Federal, entities through data files or downloads from Web sites, and loaded into the USGS NWIS (U.S. Geological Survey, 2014):

- Colorado-Division of Water Resources (also known as the Office of the State Engineer);

- Kansas-Department of Agriculture, Division of Water Resources and the Kansas Geological Survey (Kansas Geological Survey, 2014);

- Nebraska-Central Nebraska Public Power and Irrigation District, applicable Natural Resources Districts, and the University of Nebraska-Lincoln, Conservation and Survey Division;

- New Mexico-Office of the State Engineer;

- Oklahoma-Water Resources Board;

- South Dakota - Department of Environment and Natural Resources;

- Texas-Groundwater Conservation Districts and the Water Development Board (Texas Water Development Board, 2014);

- Wyoming-State Engineer's Office; and

- Federal-Bureau of Reclamation, U.S. Fish and Wildlife Service, and USGS offices in Colorado, Kansas, Nebraska, New Mexico, Oklahoma, South Dakota, Texas, and Wyoming.

The data used in this report were retrieved for each applicable State from USGS NWIS (U.S. Geological Survey, 2014).

\section{Water-Level Changes}

Water-level changes in the High Plains aquifer are presented for two periods: predevelopment to 2013 and 2011-13. In addition, water-level changes are presented as the percentage change in saturated thickness from predevelopment to 2013.

\section{Water-Level Changes, Predevelopment to 2013}

The map of water-level changes in the High Plains aquifer, predevelopment to 2013 (fig. 1), is based on water levels from 3,349 wells (table 1) and on other published data (Lowry and others, 1967; Luckey and others, 1981; University of Nebraska-Lincoln, Conservation and Survey Division, 2013). The other published data were used in areas in Nebraska and Wyoming with few predevelopment water levels (fig. 1). Water-level changes in wells, predevelopment to 2013, ranged from:

- A rise of $85 \mathrm{ft}$ in Nebraska to a decline of $256 \mathrm{ft}$ in Texas;

- A rise of $38 \mathrm{ft}$ to a decline of $196 \mathrm{ft}$ in 99 percent of the wells;

- A rise of $5 \mathrm{ft}$ to a decline of $5 \mathrm{ft}$ in 36 percent of the wells; and

- A rise of $1 \mathrm{ft}$ to a decline of $1 \mathrm{ft}$ in 10 percent of the wells.

The area-weighted, average water-level change from predevelopment to 2013 was a decline of $15.4 \mathrm{ft}$ (table 2). When summarized by State, the area-weighted, average water-level 
change from predevelopment to 2013 ranged from a decline of about $41 \mathrm{ft}$ in Texas to a rise of $1.8 \mathrm{ft}$ in South Dakota (table 2). From predevelopment to 2013, not including the areas of little or no saturated thickness, water levels declined $5 \mathrm{ft}$ or more in 37 percent of the aquifer area, $10 \mathrm{ft}$ or more in 28 percent of the aquifer area, $25 \mathrm{ft}$ or more in 19 percent of the aquifer area, and $50 \mathrm{ft}$ or more in 12 percent of the aquifer area. In approximately 52 percent of the aquifer area, waterlevel changes ranged from a 5 - $\mathrm{ft}$ decline to a 5 - $\mathrm{ft}$ rise, which is considered areas of no substantial change. From predevelopment to 2013, water levels rose $5 \mathrm{ft}$ or more in 11 percent of the aquifer area and $10 \mathrm{ft}$ or more in 5 percent of the aquifer area.

Table 2. Area-weighted, average water-level changes in the High Plains aquifer, not including areas of little or no saturated thickness, predevelopment to 2013 and 2011-13, by State and as an overall total.

[Positive values for water-level rises; negative values for water-level declines]

\begin{tabular}{lcc}
\hline \multirow{2}{*}{ State } & \multicolumn{2}{c}{$\begin{array}{c}\text { Area-weighted, average water-level change, } \\
\text { in feet }\end{array}$} \\
\cline { 2 - 3 } & $\begin{array}{c}\text { Predevelopment } \\
\text { to 2013 }\end{array}$ & $\mathbf{2 0 1 1 - 1 3}$ \\
\hline Colorado & -14.3 & -2.2 \\
Kansas & -25.5 & -3.0 \\
Nebraska & -0.3 & -1.5 \\
New Mexico & -16.5 & -0.6 \\
Oklahoma & -12.3 & -2.0 \\
South Dakota & 1.8 & 0 \\
Texas & -41.2 & -3.5 \\
Wyoming & -0.8 & 0 \\
\hline High Plains & $\mathbf{- 1 5 . 4}$ & $\mathbf{- 2 . 1}$ \\
$\quad$ & & \\
\hline
\end{tabular}

\section{Water-Level Changes, 2011-13}

Water levels were measured in 7,460 wells before the irrigation season in 2011 and 2013 (table 1). Water-level changes in the measured wells ranged from

- A rise of $19 \mathrm{ft}$ in Texas to a decline of $44 \mathrm{ft}$ in Texas;

- A rise of $8 \mathrm{ft}$ to a decline of $23 \mathrm{ft}$ in 99 percent of the wells;

- A rise of $5 \mathrm{ft}$ to a decline of $5 \mathrm{ft}$ in 75 percent of the wells; and

- A rise of $1 \mathrm{ft}$ to a decline of $1 \mathrm{ft}$ in 21 percent of the wells.

Water levels declined $3 \mathrm{ft}$ or more in 43 percent of the measured wells and declined $6 \mathrm{ft}$ or more in 17 percent of the measured wells. Water levels rose $3 \mathrm{ft}$ or more in 2 percent of measured wells and rose $6 \mathrm{ft}$ or more in 1 percent of measured wells. Area-weighted, average water-level changes, 2011-13, by State ranged from a $3.5-\mathrm{ft}$ decline in Texas to no change in South Dakota and Wyoming (table 2). The area-weighted, average water-level change for the aquifer for the period 2011-13 was a decline of $2.1 \mathrm{ft}$ (table 2).

\section{Percentage Change in Saturated Thickness, Predevelopment to 2013}

Figure 2 presents water-level changes, predevelopment to 2013 , as a percentage of predevelopment saturated thickness. This map (fig. 2) is similar in some areas to the waterlevel-change map for the same period (fig. 1); however, a large water-level change would not correspond to a substantial percentage change in saturated thickness if the predevelopment saturated thickness was large relative to the water-level change. Conversely, an area with small water-level change may correspond to a large percentage change in saturated thickness if its predevelopment saturated thickness was small. By 2013, percentage change in saturated thickness as a percent of the aquifer area, not including the areas of little or no saturated thickness, was a decrease of 10 percent or more in 25 percent of the area, a decrease of 25 percent or more in 15 percent of the area, a decrease of 50 percent or more in 5 percent of the area, an increase of 10 percent or more in 1 percent of the area, and between a rise of 10 percent and a decline of 10 percent in 74 percent of the area.

\section{Change in Water in Storage, Predevelopment to 2013 and 2011-13}

The volume of water in storage in the High Plains aquifer has been estimated, using different methods, to have been about 3.20 billion acre-ft (Bacre-ft) at predevelopment (McGuire and others, 2012), 3.25 Bacre-ft in 1980 (Gutentag and others, 1984), 2.98 Bacre-ft in 2000 (McGuire and others, 2003), 2.90 Bacre-ft in 2009 (McGuire, 2011), and recalculated as about 2.96 Bacre-ft in 2009 (McGuire and others, 2012). Water in storage in the High Plains aquifer in 2013 is estimated in this report as 2.92 Bacre-ft. Water in storage for 2013 was calculated using the rasters of water-level changes for the period of 2009-11 (McGuire, 2013) and 2011-13, the raster of saturated thickness for 2009 (McGuire and others, 2012), and the raster of average-mapped specific yield (McGuire and others, 2012).

Water in storage, predevelopment to 2013, which was calculated using average-mapped specific yield, declined 266.7 Macre-ft for the aquifer overall (table 3) or about an 8-percent decline in storage since predevelopment (McGuire and others, 2012). Changes in storage, predevelopment to 2013, by State, ranged from a decline of about 158.2 Macre-ft 


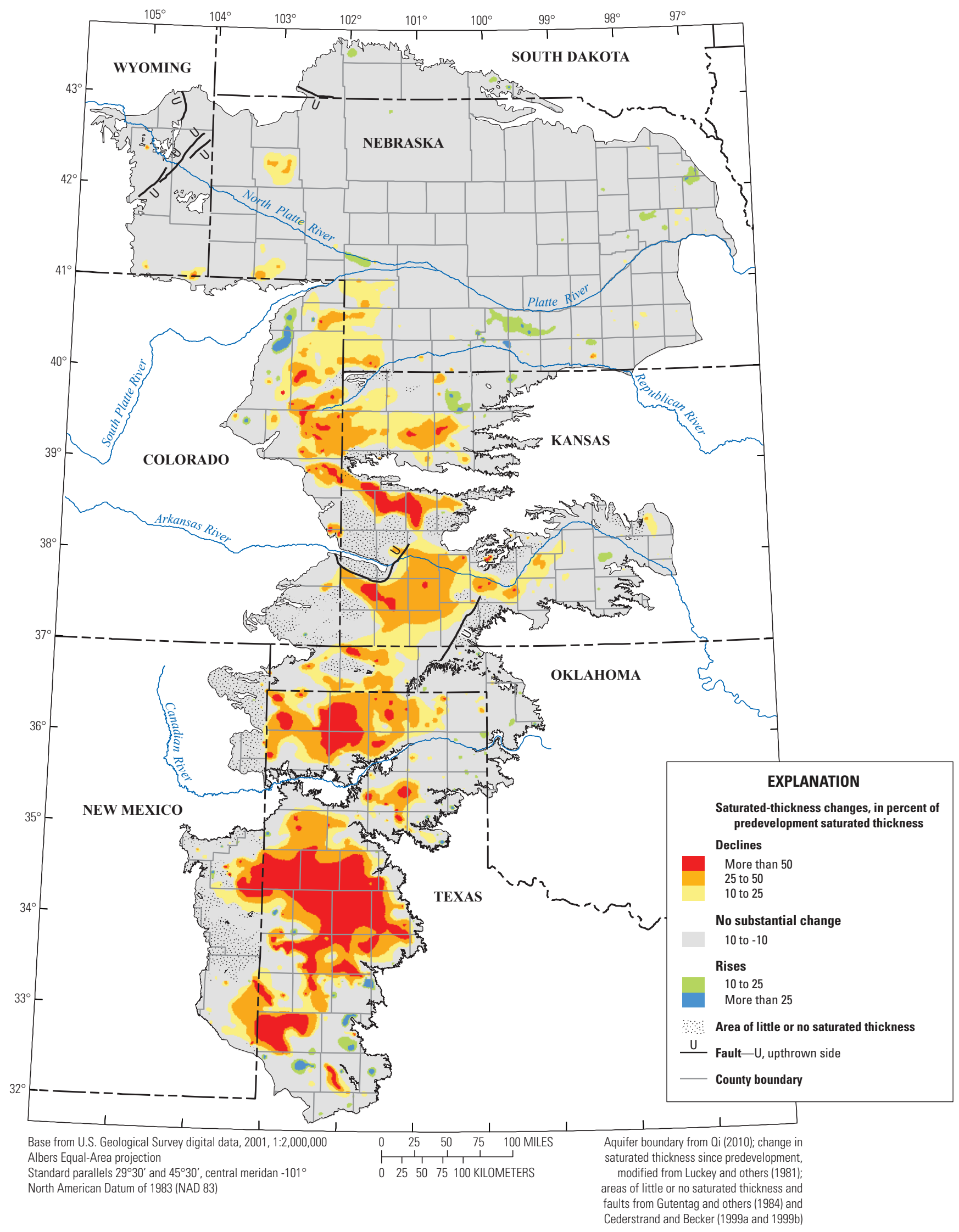

Figure 2. Change in saturated thickness of the High Plains aquifer, predevelopment (about 1950) to 2013. 
in Texas to a rise of 0.4 Macre-ft in South Dakota (table 3). Water in storage, 2011-13, declined 36.0 Macre-ft overall; changes in water in storage, 2011-13, by State ranged from a decline of 13.2 Macre- $\mathrm{ft}$ in Texas to no change in South Dakota and Wyoming (table 3).

Table 3. Change in water in storage in the High Plains aquifer, predevelopment to 2013 and 2011-13, by State and as an overall total.

[Positive values for increases in water in storage; negative values for decreases in water in storage]

\begin{tabular}{lcc}
\hline & \multicolumn{2}{c}{$\begin{array}{c}\text { Change in water in storage, } \\
\text { in million acre-feet }\end{array}$} \\
\cline { 2 - 3 } \multicolumn{1}{c}{ State } & $\begin{array}{c}\text { Final values calculated for this report, with } \\
\text { average-mapped specific yield } \\
\text { (range of 2.5 to 27.5 percent) }\end{array}$ \\
\cline { 2 - 3 } & $\begin{array}{c}\text { Predevelopment } \\
\text { to } \mathbf{2 0 1 3}\end{array}$ & $\mathbf{2 0 1 1 - 1 3}$ \\
\hline Colorado & -18.8 & -3.0 \\
Kansas & -67.5 & -8.3 \\
Nebraska & -2.0 & -9.6 \\
New Mexico & -9.7 & -0.3 \\
Oklahoma & -10.5 & -1.6 \\
South Dakota & 0.4 & 0 \\
Texas & -158.2 & -13.2 \\
Wyoming & -0.4 & 0 \\
\hline High Plains & $-\mathbf{2 6 6 . 7}$ & $\mathbf{- 3 6 . 0}$ \\
\hline aquifer & & \\
\hline
\end{tabular}

\section{Summary}

The High Plains aquifer underlies 111.8 million acres (about 175,000 square miles) in parts of eight States-Colorado, Kansas, Nebraska, New Mexico, Oklahoma, South Dakota, Texas, and Wyoming. Water-level declines began in parts of the High Plains aquifer soon after the onset of substantial irrigation with groundwater (about 1950). In response to the water-level declines, Congress directed the U.S. Geological Survey to monitor water levels in the High Plains aquifer. Since 1987, the USGS, in collaboration with numerous State, local, and Federal water-resources entities, have compiled water levels from wells completed in the High Plains aquifer. Water levels were measured in 8,332 wells for 2011 and measured or estimated in 8,613 wells for 2013 .

This report presents water-level changes in the High Plains aquifer from predevelopment (generally before 1950) to 2013 and from 2011 to 2013 . The water levels used in this report generally were measured in winter or early spring, when irrigation wells typically were not pumping, and after water levels generally had recovered from pumping during the previous irrigation season. The report also presents total water in storage in 2013 and changes in water in storage and in saturated thickness from predevelopment to 2013. The methods to calculate area-weighted, average water-level changes; changes in water in storage; and total water in storage for this report used geospatial data layers organized as rasters with a cell size of 500 meters by 500 meters, which is an area of about 62 acres. These methods provide a raster dataset of water-level changes, predevelopment to 2013, for other uses.

The map of water-level changes in the High Plains aquifer from predevelopment to 2013 is based on water levels from 3,349 wells and other published data. Water-level changes from predevelopment to 2013, in individual wells, ranged from a rise of 85 feet (ft) in Nebraska to a decline of $256 \mathrm{ft}$ in Texas. The area-weighted, average water-level change from predevelopment to 2013 was an overall decline of $15.4 \mathrm{ft}$.

Water levels were measured in 7,460 wells before the irrigation season in 2011 and 2013; water-level changes in the measured wells ranged from a $44-\mathrm{ft}$ decline in Texas to a $19-\mathrm{ft}$ rise in Texas. The area-weighted, average water-level change in the High Plains aquifer from 2011 to 2013 was a decline of $2.1 \mathrm{ft}$.

Total water in storage in 2013 was about 2.92 billion acre-feet overall, which was a decline of about 266.7 million acre-feet (or about 8 percent) since predevelopment. Water in storage, 2011-13, declined 36.0 Macre-ft overall; changes in water in storage, 2011-13, by State ranged from a decline of 13.2 Macre-ft in Texas to no change in South Dakota and Wyoming . By 2013, 15 percent of the aquifer area had a decrease in saturated thickness of more than 25 percent from its predevelopment saturated thickness, 5 percent of the aquifer area had more than a 50-percent decrease, and about 1 percent of the aquifer area had more than a 10-percent increase.

\section{References Cited}

Alley, W.M., Reilly, T.E., and Franke, O.L., 1999, Sustainability of ground-water resources: U.S. Geological Survey Circular 1186, 79 p. [Also available at http://pubs.usgs.gov/ circ/circ1186/.]

Cederstrand, J.R., and Becker, M.F., 1998, Digital map of specific yield for High Plains aquifer in parts of Colorado, Kansas, Nebraska, New Mexico, Oklahoma, South Dakota, Texas, and Wyoming: U.S. Geological Survey Open-File Report 98-414: accessed August 2011 at http://water.usgs. gov/GIS/metadata/usgswrd/XML/ofr98-414.xml.

Cederstrand, J.R., and Becker, M.F., 1999a, Digital map of geologic faults for the High Plains Aquifer in parts of Colorado, Kansas, Nebraska, New Mexico, Oklahoma, South Dakota, Texas, and Wyoming: U.S. Geological Survey Open-File Report 99-261: accessed August 2011 at http:// water.usgs.gov/GIS/metadata/usgswrd/XML/ofr99-261.xml. 
Cederstrand, J.R., and Becker, M.F., 1999b, Digital map of areas of little or no saturated thickness for the High Plains Aquifer in parts of Colorado, Kansas, Nebraska, New Mexico, Oklahoma, South Dakota, Texas, and Wyoming: U.S. Geological Survey Open-File Report 99-266: accessed August 2011 at http://water.usgs.gov/GIS/metadata/ usgswrd/XML/ofr99-266.xml.

Cunningham, W.L., and Schalk, C.W., comps., 2011, Groundwater technical procedures of the U.S. Geological Survey: U.S. Geological Survey Techniques and Methods, book 1, chap. A1, 151 p., accessed October 2014 at http://pubs.usgs. gov/tm/lal/.

Esri, 1992, Understanding GIS-The Arc/Info method: Redlands, Calif., Esri, 450 p.

Esri, 2010, ArcDoc version 9.3: Redlands, Calif., Esri software documentation [on-line documentation and instructions included with GIS software].

Gutentag, E.D., Heimes, F.J., Krothe, N.C., Luckey, R.R., and Weeks, J.B., 1984, Geohydrology of the High Plains aquifer in parts of Colorado, Kansas, Nebraska, New Mexico, Oklahoma, South Dakota, Texas, and Wyoming: U.S. Geological Survey Professional Paper 1400-B, 63 p. [Also available at http://pubs.usgs.gov/pp/1400b/report.pdf.]

Heimes, F.J., and Luckey, R.R., 1982, Method for estimating historical irrigation requirements from ground water in the High Plains in parts of Colorado, Kansas, Nebraska, New Mexico, Oklahoma, South Dakota, Texas, and Wyoming: U.S. Geological Survey Water-Resources Investigations Report 82-40, 64 p.

Kansas Geological Survey, 2014, Wizard water well levels database: Lawrence, Kansas Geological Survey digital data: accessed July 2014 at http://www.kgs.ku.edu/Magellan/ WaterLevels/index.html.

Kenny, J.F., Barber, N.L., Hutson, S.S., Linsey, K.S., Lovelace, J.K., and Maupin, M.A., 2009, Estimated use of water in the United States in 2005: U.S. Geological Survey Circular 1344, 52 p. [Also available at http://pubs.usgs.gov/ circ/1344/.]

Lowry, M.E., Crist, M.A., and Tilstra, J.R., 1967, Geology and ground-water resources of Laramie County, Wyoming, with a section on Chemical quality of ground water and of surface water, by J.R. Tilstra: U.S. Geological Survey Water-Supply Paper 1834, 71 p. [Also available at http:// pubs.er.usgs.gov/publication/wsp1834.]

Luckey, R.R., and Becker, M.F., 1999, Hydrogeology, water use, and simulation of flow in the High Plains aquifer in northwestern Oklahoma, southeastern Colorado, southwestern Kansas, northeastern New Mexico, and northwestern Texas: U.S. Geological Survey Water-Resources Investigations Report 99-4104, 68 p. [Also available at http://pubs. usgs.gov/wri/wri994104/.]
Luckey, R.R., Gutentag, E.D., and Weeks, J.B., 1981, Waterlevel and saturated-thickness changes, predevelopment to 1980, in the High Plains aquifer in parts of Colorado, Kansas, Nebraska, New Mexico, Oklahoma, South Dakota, Texas, and Wyoming: U.S. Geological Survey Hydrologic Investigations Atlas HA-652, 2 sheets, scale 1:2,500,000. [Also available at http://pubs.er.usgs.gov/publication/ ha652.]

Maupin, M.A., and Barber, N.L., 2005, Estimated withdrawals from principal aquifers in the United States, 2000: U.S. Geological Survey Circular 1279, 46 p. [Also available at http://pubs.usgs.gov/circ/2005/1279/.]

McGuire, V.L., 2003, Water-level changes in the High Plains aquifer, predevelopment to 2001, 1999 to 2000, and 2000 to 2001: U.S. Geological Survey Fact Sheet 078-03, 4 p. [Also available at $h t t p: / / p u b s . u s g s . g o v / f s / F S 078-03 /$.

McGuire, V.L., 2009, Water-level changes in the High Plains aquifer, predevelopment to 2007, 2005-06, and 2006-07: U.S. Geological Survey Scientific Investigations Report 2009-5019, 9 p. [Also available at http://pubs.usgs.gov/ sir/2009/5019/.]

McGuire, V.L., 2011, Water-level changes in the High Plains aquifer, predevelopment to 2019, 2007-08, and 2008-09, and change in water in storage, predevelopment to 2009: U.S. Geological Survey Scientific Investigations Report 2011-5089, 13 p. [Also available at http://pubs.usgs.gov/ sir/2011/5089/.]

McGuire, V.L., 2013, Water-level and storage changes in the High Plains aquifer, predevelopment to 2011 and 2009-11: U.S. Geological Survey Scientific Investigations Report 2012-5291, 15 p. [Also available at http://pubs.usgs.gov/ sir/2012/5291/.]

McGuire, V.L., Johnson, M.R., Schieffer, R.L., Stanton, J.S., Sebree, S.K., and Verstraeten, I.M., 2003, Water in storage and approaches to ground-water management, High Plains aquifer, 2000: U.S. Geological Survey Circular 1243, 51 p. [Also available at $h t t p: / / p u b s . u s g s . g o v / c i r c / 2003 / c i r c 1243 /$.]

McGuire, V.L., Lund, K.D., and Densmore, B.K., 2012, Saturated thickness and water in storage in the High Plains aquifer, 2009, and water-level changes and changes in water in storage in the High Plains aquifer, 1980 to 1995,1995 to 2000, 2000 to 2005, and 2005 to 2009: U.S. Geological Survey Scientific Investigations Report 2012-5177, 28 p. [Also available at $h t t p: / / p u b s . u s g s . g o v /$ sir/2012/5177/.]

Meinzer, O.E., 1923, Outline of ground-water hydrology, with definitions: U.S. Geological Survey Water-Supply Paper 494, 71 p. [Also available at http://pubs.usgs.gov/wsp/0494/ report.pdf.] 
Qi, Sharon L., 2010, Digital map of aquifer boundary for the High Plains aquifer in parts of Colorado, Kansas, Nebraska, New Mexico, Oklahoma, South Dakota, Texas, and Wyoming: U.S. Geological Survey Data Series 543. [Also available at $h t t p: / / p u b s . u s g s . g o v / d s / 543 /$.

Taylor, C.J., and Alley, W.M., 2001, Ground-water-level monitoring and the importance of long-term water-level data: U.S. Geological Survey Circular 1217, 68 p. [Also available at http://pubs.usgs.gov/circ/circ1217/.]

Texas Water Development Board, 2014, Groundwater database: Austin, Texas Water Development Board digital data: accessed May 2014 at http://www.twdb.state.tx.us/ groundwater/data/gwdbrpt.asp.

Thelin, G.P., and Heimes, F.J., 1987, Mapping irrigated cropland from Landsat data for determination of water use from the High Plains aquifer in parts of Colorado, Kansas, Nebraska, New Mexico, Oklahoma, South Dakota, Texas, and Wyoming: U.S. Geological Survey Professional Paper 1400-C, 38 p. [Also available at http://pubs.usgs.gov/ pp/1400c/report.pdf.]

Tomlin, C.D., and Berry, J.K., 1979, A mathematical structure for cartographic modeling in environmental analysis, in American Congress on Surveying and Mapping, 39th, Washington, D.C., 1979, Proceedings: Falls Church, Va., American Congress on Surveying and Mapping, p. 269283.
U.S. Department of Agriculture, 1999, 1997 Census of agriculture, volume 1, geographic area series, part 51: National Agricultural Statistics Service, AC97-CD-VOL1-1B, CDROM.

U.S. Department of Agriculture, 2004, 2002 Census of agriculture, volume 1, chapter 2, County level data: National Agriculture Statistics Service: accessed July 2006 at http:// www.agcensus.usda.gov/Publications/2002/index.asp.

U.S. Geological Survey, 2008, Water use in the United States: U.S. Geological Survey digital data [groundwater-use data by county for 1985, 1990, 1995, 2000 and 2005]: accessed December 2008 at http://water.usgs.gov/watuse/.

U.S. Geological Survey, 2014, National Water Information System: U.S. Geological Survey digital data: accessed January to August 2014 at http://waterdata.usgs.gov/nwis/gw.

University of Nebraska-Lincoln, Conservation and Survey Division, 2013, Groundwater-level changes in Nebraska from predevelopment to spring 2013: Lincoln, University of Nebraska-Lincoln, Conservation and Survey Division, digital map graphic: accessed September 2014 at http://snr. unl.edu/data/water/groundwatermaps.asp.

Weeks, J.B., and Gutentag, E.D., 1981, Bedrock geology, altitude of base, and 1980 saturated thickness of the High Plains aquifer in parts of Colorado, Kansas, Nebraska, New Mexico, Oklahoma, South Dakota, Texas, and Wyoming: U.S. Geological Survey Hydrologic Investigations Atlas HA-648, 2 sheets, scale 1:2,500,000. [Also available at http://pubs.er.usgs.gov/publication/ha648.] 

Appendix 


\section{Appendix. Raster Datasets}

Raster datasets are presented for figure 1, which is a map depicting water-level changes, predevelopment to 2013. The raster dataset is presented in both Esri® ${ }^{\circledR}$ ArcInfo ${ }^{\mathrm{TM}}$ Workstation, version 10.0 (Esri, 1992 and 2010) grid and ASCII format at the following URLs:

- Esri ${ }^{\circledR}$ grid format: $h t t p: / / w a t e r . u s g s . g o v / G I S / d s d l / s i r 2014-5218 \_h p \_w l c p d 13 g . z i p$

- ASCII format: http://water.usgs.gov/GIS/dsdl/sir2014-5218_hp_wlcpd13a.zip 
Publishing support provided by:

Rolla Publishing Service Center

For more information concerning this publication, contact: Director, USGS Nebraska Water Science Center

5231 South 19th Street

Lincoln, Nebraska 68512

(402) 328-4100

Or visit the Nebraska Water Science Center Web site at: http://ne.water.usgs.gov/ 




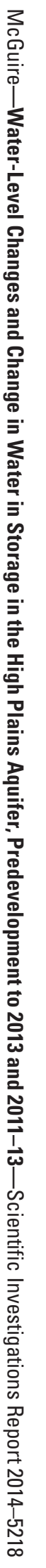

